\title{
The Existence of Bagurau Tradition on Instagram
}

\author{
E Meigalia $^{1}$, Y S Putra ${ }^{2}$ \\ \{1ekameigalia@hum.unand.ac.id, ${ }^{2}$ yerri@hum.unand.ac.id \} \\ ${ }^{1,2}$ Universitas Andalas Padang, Indonesia
}

\begin{abstract}
Bagurau is a Minangkabau oral tradition that existed long before media technology developed as it is today. Of the many oral traditions that have disappeared and can no longer survive in this era, it still survives. Even this tradition is present in various social media that are now. This article explains the form of bagurau tradition of survival in the era of media technology with a focus on observations on Instagram social media. For this reason, qualitative methods are used with data collection techniques through observation on Instagram media. Based on these studies, bagurau is one of the popular Minangkabau oral traditions. Even some accounts make this tradition a superior content that not only increases the popularity of the account but also adds money to the entry.
\end{abstract}

Keywords: Bagurau, Instagram, Minangkabau, Oral tradition, Social media

\section{INTRODUCTION}

Today's social media has become a necessity for the community. Perrin [1] explained that from 2005 to 2015, social media users continued to show improvement. It also has an impact on various aspects of people's lives. Correspondingly, O, Keeffe [2] states that activities on social media today are common to the community, especially for children and adolescents. The use of social media continues to grow into the business world. Social media is not only used as a medium of communication and interaction but also can be a business tool [3] [4].

The use of social media as a means of business has resulted in the emergence of various content on social media. These are made as attractive and creative as possible to increase the number of followers, enthusiasts, or those who see. One of them is by utilizing oral traditions which began to be considered as something rare and classic. Only a few people understand and master it. Because of that scarcity, oral traditions that appear on social media continue to be seen and liked.

Bagurau is one of them. This oral tradition that emerged and developed in Minangkabau has appeared on Instagram social media as one of the creative contents of the account owner. Bagurau tradition itself is a form of snatching of the pantun which is accompanied by a wind instrument called saluang [5]. The rhymes that are sung by the theme and the contents are not bound. Can always be adjusted to the current conditions and situations. Generally, the themes that often arise are sadness, excitement, and satire.

Compared to other Minangkabau oral traditions, bagurau is one that still survives and is liked today. Meanwhile, other oral traditions as mapped by Amir and friends [6] have been lost. Entering the era of secondary oralism (the term Walter J. Ong [7]), oral traditions must continue to strive to be creative and innovative to survive as explained by Banda [8]. It is also one of the reasons why bagurau tradition can continue to survive. 
Through this article, we describe the form of content that utilizes bagurau's oral tradition on social media. As explained by Cahyono [9], social media since 2003 has emerged many and varied. Among the biggest to date are Facebook, Twitter, Instagram, and WhatsApp. Each has its advantages and advantages. In each of the social media, the bagurau tradition can be found. But for this article, the study of the existence and existence of the bagurau tradition on social media is focused on Instagram media. Instagram was chosen because social media is currently popular. Apart from being able to share photos, you can also share videos and live broadcasts so that it is very appropriate to be used as a means of documentation and socialization of oral traditions such as bagurau to continue to exist.

Research related to the bagurau tradition has been carried out by several previous researchers. Among them is Anwar [10] which explains the bagurau tradition as a Minangkabau oral tradition that emerged and developed in the Luhak Nan Tigo region (Agam, Tanah Datar, and Lima Puluh Kota). Then Sriyanto [11] with his research on the aesthetic dimension of bagurau performances in Minangkabau. Meanwhile, the speaker of this tradition called the drummer was also investigated by Syafniati [12], namely focusing on female drummers. Next is Alexander's [13] research on postmodern influences in the saluang bagurau show.

Related to the use of social media and its relation to oral tradition or folklore, researchers who have discussed it include Hidayat [14] with a study of the transfer of media kaba, Bahren [15] with a creative industry based on socio-cultural fields in West Sumatra, Meigalia [16] [ 17] with attention to social media and its use of Minangkabau oral literature, and Polk [18] who discussed the practice of online digital storytelling. Meanwhile, various forms of Instagram social media users have also been a concern for some researchers. Among them were Yuheng [19] who discussed photo content and types of Instagram usage, Sheldon [20] who saw the motivations of age-related Instagram users, and Indrawati [21] which explained the effectiveness of advertising through the use of Facebook and Instagram with case studies towards marketing souvenirs in Bali.

\section{RESEARCH METHOD}

This research was designed as qualitative research. Oral tradition itself is a unique object that requires methods and techniques that are also specialized in researching [22]. Therefore the oral tradition research stage must be carried out in four stages: First, the pre-research is in place which is the preparation stage before the data collection in the field is carried out. Both studies are in place which aims to collect data in this case by observing, interviewing, and studying literature. Third, the stage of data identification and analysis. Fourth, the reporting phase. However, research with the object of study of the bagurau oral tradition is focused on its appearance on Instagram social media. For this reason, data collection techniques are also carried out through observation and recording on Instagram with hashtag saluang, bagurau (\#saluang, \#bagurau). The data is then classified based on the content models that appear.

Also, a literature review which has gone through the stage of data collection in the field is still being carried out. In this case, previous studies of the bagurau tradition were used to better understand and trace the picture of the whole bagurau tradition.

\section{RESULT AND DISCUSSION}

Bagurau is a Minangkabau oral tradition which is often referred to as badendang or basaluang. Amir [6] explained this tradition as sundown of the rhyme with the accompaniment of the saluang wind instrument. Saluang is a traditional wind instrument from Minangkabau 
made of bamboo and has four holes to produce tones. The rhythms of the rhyme in the bagurau are various, including ratok, and singgalang. Meanwhile, the rhymes that were sung were pantun with various themes, sometimes the theme was adjusted to the audience's request. There is also a theme of rhyme that often appears in the bagurau including grief, innuendo, and seduction. The rhyme was created spontaneously by the drummer.

In one performance, there are at least two performers. First is the saluang player (tukang saluang) who is generally male. Then the singer (tukang dendang) can be a woman and can be a man. But female drummers are more numerous than male singer. In one show, the number of singer can be more than one.

Bagurau shows are usually held at night, the purpose of which is entertaining. Therefore, bagurau shows can be carried out anywhere, can be at home in a festive event, at the storefront, or in alek nagari activities. One of the most liked parts of the audience is ordering songs and rhymes by giving money to the drummer. Because of the rhymes and order songs among the audience, the atmosphere of the show became lively and very entertaining.

This bagurau show has existed long before the development of media technology and information today. In the past, bagurau became one of the few entertainments for the community. The bagurau show is always awaited and has lots of fans. They even want to sit for long listening to the poems that are heard overnight. Therefore, the performance usually ends just before Fajr time.

Along with the development of technology, people began to have many entertainment choices. Entertainment can be obtained only by sitting at home. This is partly due to the presence of television and radio media. In this period, the tradition of bagurau was able to continue to survive and adjust to the changing lives of these people. One of them is present in the form of shows on television, radio, as well as records of both LPs, cassettes, and VCDs [23] [24].

At present, the lives of people in the world have entered the stage called the term 4.0 industrial revolution. in this era, various aspects of people's lives depend on the internet [25]. Various aspects of life and community needs are presented with internet brokers, such as through social media. Social media in various previous studies mentioned are used by the community as a means of communicating, socializing, even doing business.

Bagurau tradition also seems to have been present on various social media. One of them on Instagram. This tradition is presented with various creative models. There are several forms of content on Instagram that use bagurau traditions. First is the documentation of the bagurau show that was encountered by users around it. The show is documented as it is, without being intended by the performer (tukang saluang and tukang dendang) to be posted on social media. Therefore, the form of upload is not through an editing process or special settings. One of them was uploaded to the @kikochaniago account on August 16, 2017, with information from Mudiak Arau. The post on this account is a brief documentation of the bagurau show in the courtyard of the Jam Gadang, Bukittinggi. The post has aired 1,528 times. Furthermore, the $@$ rinisfhari account also posted documentation on the performance of Bagurau on June 27, 2019. The upload was given the information " Semoga kesenian khas masyarakat Minangkabau ini tak akan hilang tergerus zaman. Semoga bisa terus dilestarikan. Sedih aja kalo dengar ini. Ibo ati ". The post just got 13 likes so far. Then post from the account @ febri.mayora with the description " Kesenian saluang minang yang dipadukan dengan dangdut ". The documentation of the dangdut saluang show was uploaded on December 22, 2018, and has been aired 370 times.

The second form of content that uses the bagurau tradition is a video of a saluang player playing a saluang instrument without being accompanied by a tukang dendang (singer). The saluang player here also organizes the appearance specifically because it aims to be published 
on Instagram social media. Posts such as those intended include posted via the @ pa.ul.ikram account with the statement "Saluang salah satu kesenian tradisional Minangkabau, suatu kesenian yang khas dan hanya ada di ranah bundo, beberapa lapisan masarakat masih sadar akan itu, dan beberapa kalangan sangat mecintai kesinian ini, namun beberapa oknum menganggapnya kuno dan tidak relefan lagi dengan zaman sekarang ini. " In the video, a young man wearing a sarong, playing a musical instrument saluang. Next to it is a classic Vespa motorbike that seems to be deliberately one part of the video background to make it more attractive. The video uploaded on July 12, 2019, has been aired 522 times. Next, the post on the @ minangkabau_ekspres account with the information "Mantap pak KAI Punya @)". Since July 19,2018 , the post in the form of a video of an Indonesian Railroad employee who was playing the saluanhg musical instrument has 1,122 shows. Not much different from the @ ilhampr4 post, in the form of a video showing him playing saluang. The post-dated March 6, 2019, was given the statement "Masih belajar" and had aired 284 times.

Next, the third form of content on Instagram that uses the bagurau tradition is complete video footage of the performance of bagurau, which is a saluang player and a singer. But the footage of the bagurau tradition is a fictitious result that was intentionally intended to be content on Instagram. Postings like that are uploaded via the @ padang_maimbau account with the description " Salamaik siang sanak sadonyo. Ko cover lagu (minang-mudiak arau) bersama uni cantik kita dari payakumbuh @ellayuliafebrianti. Yang mau request langsung DM aja ya. Selamat menikmati ". The April 5 posting was favored by 59 accounts. Then posting in the @ kharisma.iie account in the form of a video that chants with the accompaniment of artisan saluang@ cabiak. Uploaded on 30 April 2019 has been broadcast 14,040 times. The video was made with a Twin Tower background, Malaysia.

Finally, the form of content that is raised is the raiding of rhymes for bagurau without the accompaniment of saluang music. The pantun was deliberately created and sung according to the context that was loved by young people. Among them, the theme does not yet have a partner. The rhyme and lose rhyme from the bagurau tradition is well utilized by the @ urianovita account as its creative content. One of the posts was May 4, 2019. Uria Novita as the account owner sang the following poems.

\section{Urang Pandam mandi barampek \\ Daun pandan di rumpun padi \\ Salam basalam kok tak dapek \\ Tarimo lah dendang ka ganti diri \\ Bara ka sanang dalam hati tuan oi \\ Anak mudo jalan barampek \\ Singgah sabanta di Sicincin \\ Bulan Puaso samakin dakek \\ Mohon maaf lahia jo batin \\ Bara ka sanang kiro-kiro sanak oi}

The pantun was arranged to convey his apologies in welcoming the month of Ramadan. In that post, there was also information " Dek puaso samakin dakek, tarimo lah dendang ka ganti diri" and had aired 84,601 times.

On the same account, there is also the following kick post. 
Kok ndak babaliak uda dari rantau

Elok adiak baralek sajo

Baralek nan jo urang lain

Tunggu dek uda undangannyo

Tangguang dek uda sansaronyo

Nan dek rantau lah jauah bananyo

Lah lupo sajo status marando

Dima nan jauah ka takana

Di kampuang elok ka gantinyo

Dek panantian lah sio-sio

Nan manakua duduak ka bumi

Maningadah ka awang-awang

Taraso bana tinggi langik

Kasiah dirabuik samo gadang

Kasiah dirabuik samo gadang

The pantun insinuated the nomads who were so late overseas that they forgot about kampong. As a result, the future wife was impatiently waiting and threatened to send an invitation. The post on December 21, 2018, has been broadcast 81,547 times. Almost as much as the other posts.

This@urianovita account is indeed interesting because it maximally utilizes the bagurau tradition as its creative content. Because the content is also followers of Instagram account has reached 60,000 and has received an endorsement. One of them is from the Tangkelek business owner. Interestingly, Tangkelek's business promotion on this account was also made in the form of a rhyme drum like the following.

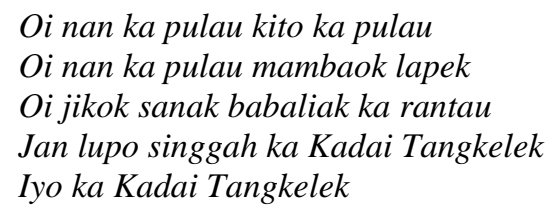

The creativity of Uria Novita through the Instagram account was also followed by an account @ kharisma.iie. In this account, you can also find several shaky posts from the bagurau tradition. Among them are the posts dated June 22, 2019, with the statement " Dendang Aia Bangih. Untuak dunsanan nan banyak man DM dendang iko". The post has aired 4,225 times. Not like the @urianovita account, this account has only 4,552 followers. But the name Kharisma has also become popular because of his kick.

As far as the search, bagurau tradition artists who have an Instagram account and use the account as a promotional media are only one account. This account belongs to Hasanawi who is a saluang player. His new account @ langkok.grup has 18 posts and 478 followers. But as a whole, the account indeed fully displays various activities and activities in basaluang. However, the use of this account is also not maximal because, since the first post on February 20, 2018, there are only 18 posts.

Based on the data that has been obtained, it can be seen that the bagurau tradition has indeed been used by account owners on Instagram as their creative content [26]. Furthermore, the bagurau tradition was introduced to a wider audience through social media. That is, this 
tradition has been able to continue to survive and exist in the era of internet technology like now. On the other hand, the account owner who uploaded this tradition also became existent. Even from the data above, the @ urianovita account has succeeded in making its Instagram account a business tool by utilizing the bagurau tradition.

\section{CONCLUSIONS}

Bagurau tradition is currently present on social media as one of the creative contents of account owners. The form of using this bagurau tradition also has several models. The first is a short documentary video of bagurau performances that are encountered by account owners in various places. Both videos play a saluang wind instrument without a drum which is deliberately made for the sake of posting on social media. The three complete video posts are bagurau performances (there are saluang and tukang dendang players). But this brief briefing is also deliberately made for the sake of posting on social media. Finally, the post kicked bagurau without accompaniment saluang.

There are also posts with hashtag saluang and bagurau found quite a lot. Spread from various accounts. On the one hand, the bagurau tradition has been introduced to a wider audience through these posts. This can be seen from the many who like or even the number of broadcast posts. That way, the tradition of bagurau can continue to live, be recognized, and also adjust to the changes that exist in society. Bagurau tradition can also be said to be one of the Minangkabau oral traditions which are not feared to be lost.

On the other hand, the tradition of bagurau has also provided its benefits for account owners. The account owner is generally preferred and seen more for these posts. Also, the two account owners on Instagram have made the bagurau tradition a special content. Because the content is also the account has many followers. Furthermore, account owners also get financial benefits with many followers

\section{ACKNOWLEDGEMENT}

The author expresses gratitude to Lembaga Penelitian dan Pengabdian kepada Masyarakat Universitas Andalas, Universitas Andalas, Program Studi Sastra Minangkabau Universitas Andalas, and Asosiasi Dosen Pendidikan Bahasa Indonesia.

\section{REFERENCES}

[1] A. Perrin, "Social Media Usage: 2005-2015," 2015.

[2] G. S. O'Keeffe and K. Clarke-Pearson, "The Impact of Social Media on Children, Adolescents, and Families," Pediatrics, vol. 127, no. 4, pp. 800-804, 2011.

[3] S. Edosomwan, "The History of Social Media and its Impact on Business," Journal of Applied Management and Entrepreneurship, vol. 16, no. 3, p. 79, 2011.

[4] S. SI, "Social Media and Its Role in Marketing," Business and Economics Journal, vol. 07, no. 01, pp. 1-5, 2015.

[5] N. Sukmawati, Ratapan Perempuan Minangkabau dalam Pertunjukan Bagurau, Gambaran Perubahan Sosial Minangkabau. Padang: Andalas University Press, 2006.

[6] D. Amir, Adriyetti., Pemetaan Sastra Lisan Minangkabau. Padang: Andalas University Press, 2006.

[7] W. J. Ong, Orality and Literacy. The Technologization of the Word, vol. 58. Londres y Nueva York: Routledge, 2002. 
[8] M. M. Banda, "Tradisi Lisan dan Kelisanan Sekunder di Era Globalisasi," in Seminar Seri Fakultas Ilmu Budaya Universitas Udayana, 2016, pp. 1-20.

[9] W. Errika, "Komunikasi dan media sosial ( communications and social media )," the Messenger, vol. 3, no. 1, pp. 69-75, 2011.

[10] K. Anwar, "BAGURAU: MINANGKABAU ORAL LITERATURE IN LUHAK NAN TIGO WEST SUMATRA,” e-Journal of Linguistics, vol. 4, no. 2, 2012.

[11] Sriyanto, "Dimensi Estetika Pertunjukan Saluang Dendang di Minangkabau dalam Bagurau," Ekspresi Seni, vol. 14, no. 2, pp. 225-236, 2012.

[12] Syafniati, "Pandangan Masyarakat Terhadap Wanita Sebagai Pendendang dalam Acara Bagurau Lapiak di Payakumbuh,” Humanus, vol. XIII, no. 2, pp. 146-155, 2014.

[13] B. Alexander, "BESAUNG JURNAL SENI Bahoyak : Pengaruh Postmodern di dalam Pertunjukan Saluang Dendang di Minangkabau," BESAUNG; Jurnal Seni Desain dan Budaya, vol. 4, no. 2, pp. 51-55, 2019.

[14] H. N. Hidayat, Wasana, and Kadrianto, "ALIH MEDIA KABA : Alternatif Revitalisasi Sastra Minangkabau," Lingua Idea, 2013.

[15] B. Bahren, H. N. N. Hidayat, S. Sudarmoko, and V. Setyaka, "Industri Kreatif Berbasis Potensi Seni Dan Sosial Budaya Di Sumatera Barat,” Ekspresi Seni, 2014.

[16] E. Meigalia and Y. S. Putra, "SASTRA LISAN DALAM PERKEMBANGAN TEKNOLOGI MEDIA: STUDI TERHADAP TRADISI SALAWAT DULANG DI MINANGKABAU," Jurnal Pustaka Budaya, 2019.

[17] E. Meigalia and Y. Putra, "Minangkabau Oral Tradition Performer and Social Media Usage," in Proceedings of the First International Conference on Advances in Education, Humanities, and Language, ICEL 2019, Malang, Indonesia, 23-24 March 2019, 2019.

[18] E. Polk, "Folk media meets digital technology for sustainable social change: A case study of the center for digital storytelling," Global Media Journal, vol. 10, no. 17, 2010.

[19] Y. Hu, L. Manikonda, and S. Kambhampati, "What We Instagram: A First Analysis of Instagram Photo Content and User Types," 2014.

[20] P. Sheldon and K. Bryant, "Instagram: Motives for its use and relationship to narcissism and contextual age," Computers in Human Behavior, 2016.

[21] K. A. P. Indrawati, N. I. Sudiarta, and W. I. Suardana, "Efektivitas Iklan Melalui Media Sosial Facebook Dan Instagram Sebagai Salah Satu Strategi Pemasaran Di Krisna Oleh-Oleh Khas Bali," Analisis Pariwisata, vol. 17, no. 2, pp. 78-83, 2017.

[22] Pudentia MPSS (Editor), "Metodologi Kajian Tradisi Lisan," Yayasan Obor Indonesia. 2015.

[23] Suryadi, "The recording industry and 'regional' culture in Indonesia," Wacana, vol. 16, no. 2, pp. 479-509, 2015.

[24] S. Suryadi, "The impact of the West Sumatran regional recording industry on Minangkabau oral literature," Wacana, Journal of the Humanities of Indonesia, vol. 12, no. 1 , p. $35,2010$.

[25] B. A. Sudramanto and Abu Salim, "Makanan Tradisional, Bahasa dan Revolusi 4.0," 2019, pp. 120-131.

[26] N. Kurniasih, E. Rizal, Y. Winoto, N. Kurniawati, A. Sudirman, A. Hasibuan, A. Daengs GS, and K. Saddhono. "Online Media as a Movie Reference." In Journal of Physics: Conference Series, vol. 1114 no. 1, p. 012087. IOP Publishing, 2018. 